\title{
Strategies to Reduce Post-Harvest Losses for Fruits and Vegetables
}

\author{
Aysel Elik (Corresponding author) \\ Engineering Faculty, Food Engineering Department, \\ University of Gaziantep, 27310 Gaziantep, Turkey \\ E-mail: aelik@gantep.edu.tr \\ Derya Kocak Yanik \\ Engineering Faculty, Food Engineering Department, \\ University of Gaziantep, 27310 Gaziantep, Turkey \\ E-mail: dkocak@gantep.edu.tr \\ Yildiray Istanbullu \\ Central Research Institute of Food and Feed Control, \\ Ministry of Agriculture and Forestry, 16036 Bursa, Turkey \\ E-mail: yildiray.istanbullu@tarimorman.gov.tr \\ Nurcan Aysar Guzelsoy \\ Central Research Institute of Food and Feed Control, \\ Ministry of Agriculture and Forestry, 16036 Bursa, Turkey \\ E-mail: nurcan.aysarguzelsoy@tarimorman.gov.tr \\ Arzu Yavuz \\ Central Research Institute of Food and Feed Control, \\ Ministry of Agriculture and Forestry, 16036 Bursa, Turkey \\ E-mail: arzu.yavuzyilmaz@tarimorman.gov.tr \\ Fahrettin Gogus \\ Engineering Faculty, Food Engineering Department, University of Gaziantep \\ 27310 Gaziantep, Turkey \\ E-mail: fahret@gantep.edu.tr
}

The research is financed by the Erasmus + Program of the European Union within the framework of the project "Best Innovative Approach to Minimize Post Harvest Losses within Food Chain for VET."

\begin{abstract}
Post-harvest loss is one of the concerns of food security and global hunger in many countries. The extent of fruit and vegetable loss reaches up to $50 \%$ thus, reducing fruit and vegetable loss and waste is the one of the leading issue for providing sustainably feeding the world's population in the future. Major causes of post-harvest losses in fruit and vegetable occur during harvesting, post-harvest handling and storage, processing stages, distribution and consumption. Therefore, the use of appropriate post-harvest handling, packaging, transportation and storage practices is very important to minimize the amount of post-harvest loss. This paper provides a review which includes causes of postharvest losses of the fruit and vegetable and appropriate methods to minimize these losses.
\end{abstract}

Keywords: post-harvest, fruit, vegetable, loss

DOI: $10.7176 / J S T R / 5-3-04$

\section{Introduction}

Demand for vegetables and fruits are increasing in parallel with population growth. According to United Nations Food and Agriculture Organization (FAO) 2016 data; over the 57 million hectares of land, 1,07 billion tons of fresh vegetables were produced all around the world. This value was 865 million tons of fresh fruit for 65 million hectares of land. 
All those involved in the process chain -as well as consumers- bear the responsibility for handling resources sparingly, protecting the environment and stemming food waste, which is now running worldwide at around 1.3 billion tons per year. In the case of fruit and vegetables, it is as much as $50 \%$ of the cultivated crops (Gustavsson et al., 2011). In other words, almost half of all cultivated products are lost before even reaching the consumption stage. Moreover, this rate is even higher in developing and underdeveloped countries. Reduction in these postharvest losses plays an important role in sustainably feeding the world's population in the future (Gustavsson et al., 2011). When considered from this point of view, the prevention or at least minimization of fresh fruits and vegetables losses becomes more of an issue. Therefore, improvements in postharvest technologies such as good harvesting practices and packaging systems are vital to minimize postharvest losses and to improve quality characteristics of fresh produce so that more fresh produce is actually consumed.

The moisture loss, bruising and subsequent decay are leading degradation types which are responsible with disposal of fresh fruits and vegetables (Kitinoja \& AlHassan, 2010; Ray \& Ravi, 2005). A number of factors (processing, storage and transport conditions) plays role on these deteriorative reactions during the journey of fruits and vegetables from grower to consumer. Knowing where the losses occur in the food supply chain is important to determine potential reasons and improve best post-harvest approaches (Gustavsson et al., 2011; Porat et al., 2018). Losses in food supply chains of fresh fruits and vegetables occur during harvesting, post-harvest handling and storage, processing stages, distribution and consumption (Figure 1). The large scales of postharvest losses are generated if these factors are not controlled properly. The changes which occur on fresh produce cannot be stopped, but it is possible to minimize with some precaution such as low temperature, relative humidity control during storage, proper packaging and transportation, etc (Ahmad \& Siddiqui, 2015).

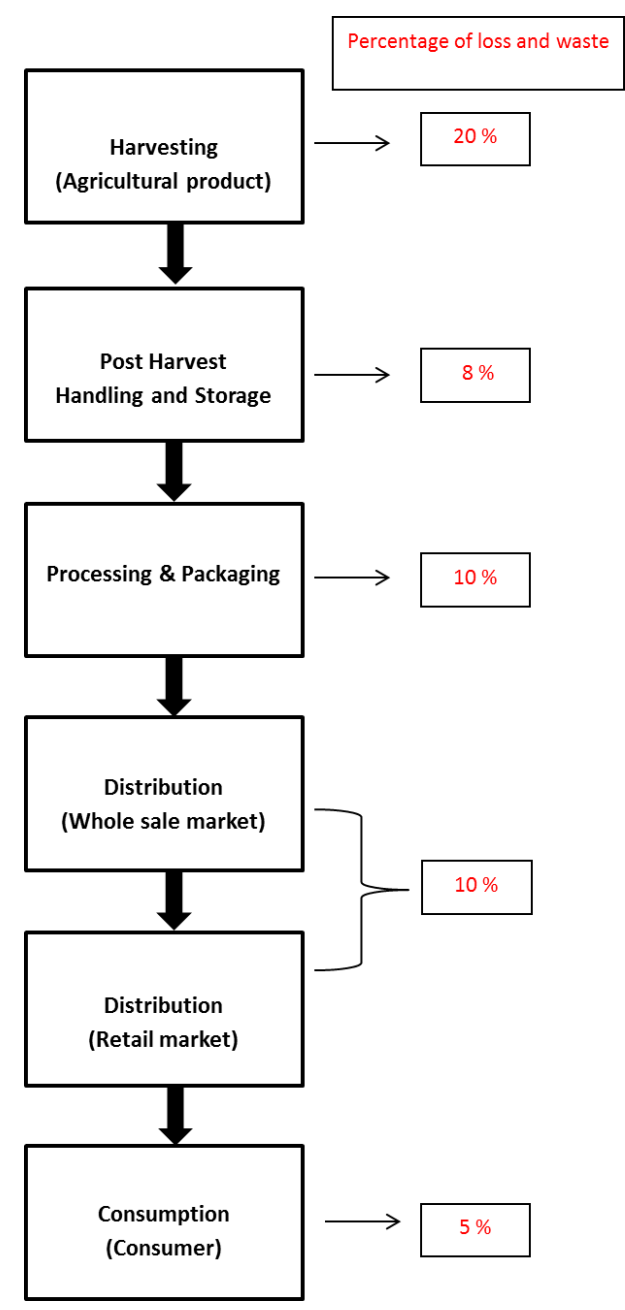

Figure 1. A flow diagram of fresh fruit and vegetable supply chain illustrating the waste generated at each stage 


\section{Causes of post-harvest losses of fruits and vegetables}

\subsection{Harvesting}

For fruit and vegetables, ripening at harvest time is the main factor that determines the product quality and the shelf life. However, some farmers can harvest immature crops due to economic reasons. Unripened fruits are more susceptible to mechanical damage and deterioration and they may have poor qualities such as high acidity and low sugar through the ripening. On the contrary, over-ripe fruits have a low shelf life. In both cases (over ripening and under ripening), fruits are more susceptible to physiological disorders. Early harvesting reduces the nutritional and economic value of crops. In some cases, whole products can be lost because they are not suitable for consumption (Azabağaoğlu, 2018; Kader, 1995).

Harvest techniques can also cause losses (Kasso \& Bekele, 2016). The losses increase when easily perishable foods such as fruits and vegetables are exposed to more than one treatment. At the same time, farmers may not have storage containers at the harvesting or after harvesting stages. This leads to mechanical damage during harvesting of fruits, vegetables and root and tuber plants, resulting in certain losses.

Incorrect application in cultural practices such as frost, hail, drought, excessive rainfall, diseases, physiological disorders, plant nutrition, plant protection, irrigation, fertilization, and pruning in the preharvest period cause fruit and vegetable losses. During the harvesting period; incorrect estimation of harvesting time, harvesting at the wrong time, improper application of harvesting practices, failure to apply pre-cooling to fruits like cherries cause the loss in the harvesting period (4-12\%) (Özdemir et al., 2003; Özcan, 2010).

\subsection{Storage}

A cold chain is a continuous supply of a product from production to consumption at a certain temperature. Continuous cold chain in perishable food ensures that the product reaches the consumer without deterioration. Effective cold chain management starts with pre-cooling and continues with cold storage, cold transport and refrigerated display cases. The International Refrigeration Institute (IIR) calculated that in developing countries $23 \%$ of the perishable foods were spoiled because of not being used the cooler (IIR, 2009).

After application of some treatments such as cleaning, sorting, and packaging on post-harvest products, it may be necessary to store the products in periods ranging from a few hours to a few months. By storing products, time management can be improved, and marketing and consumption can be done leisurely. Of course this situation is valid when the storage operation is carried out under suitable conditions; otherwise, serious losses may occur in products. Nevertheless, it should be remembered that even if the products are stored in the best conditions, the quality and consumability of the products depends on the stage of the whole food supply chain.

In developed countries, storage is uniformly provided throughout the entire supply chain from the production stage. When cold storage is combined with post-harvest technology such as a controlled atmosphere, the shelf life of perishable foods become considerably longer. The lack of proper storage facilities in developing countries is seen as the main cause of post-harvest losses (FAO, 2013).

\subsection{Transportation}

Since transportation places a certain period of time between production and consumption, it can be one of the main causes of losses, especially for fresh products. In developed countries, delivery of perishable foods with refrigerated vehicles is a standard practice. Losses in such cases occur when the cooling system in the vehicle is broken down, when an accident occurs or when there is a delay in the loading/unloading areas. In developing countries, the absence of appropriate means of transport, poor roads and inefficient logistics management prevent perishable foods from being properly preserve. In addition, loading and unloading operations are carried out in these countries by unskilled and uneducated workers who generally do not carry products carefully. This causes mechanical damage in agricultural products (Azabağaoğlu, 2018).

In many cases, food products are improperly packaged and loaded, and sometimes even they are thrown into vehicles. The poor roads in the rural areas where the majority of the production is made lead to an increase in food losses during transportation. Even in rainy times, the getting cars might get stuck in the mud leads to loss. 


\subsection{Improper packaging}

Losses can be largely prevented with timely and accurate harvesting, refrigerated car use in intercity transport, cold storage and use of packaging material that can prevent moisture loss. Farmers sell their produce in fresh markets or in wholesale markets. At the retail level, fresh produce is sold in an unpackaged form or is tied in bundles. This type of market handling of fresh produce greatly reduces its shelf life if it is not sold quickly (Kiaya, 2014).

Packaging is an important factor in reducing losses, as well as extending the shelf life of fresh fruits and vegetables. Therefore, one of the major reasons that fruits and vegetables are lost at post-harvest stages is improper packaging and use of unsuitable packaging material. Poor quality packaging materials cannot adequately protect the fresh produce from damages and can even accelerate spoilage of fresh produces. Unfortunately, low-quality packaging materials are widely used in many parts of the world due to their low cost. Especially, use of poor quality packaging container is more common in under-developed and developing countries. Even some of delicate fruit and vegetables are packed in poly-sacks that severely damage to the delicate products. According to a study carried out in some countries in Sub-Saharan Africa and South Asia, $46 \%$ of horticultural crops were packed in cloth bundles or large sacks, $31 \%$ of them were packed in open baskets and $8 \%$ had no package at all. (Kitinoja \& AlHassan, 2010).

\subsection{Consumers' waste}

Consumption stage lasts from the moment of purchase by consumers of fruit and vegetable to the moment of consumption. Considerable losses for fruit and vegetable occur at consumption stage in the food supply chain. Fresh fruit and vegetables contribute to almost $50 \%$ of food wasted by households. According to a study conducted by FAO (2011), fruit and vegetable correspond to $39 \%$ of total household waste. In another study carried out by WRAP (2008), this ratio reaches up $40 \%$ of the total household waste. The main causes of the consumers' waste are due to over-purchasing, lack of planning, poor home-storage management, etc. Magnitude of consumers' waste depends on both socio-cultural and material factors such as gender, lifestyle, income and home storage facilities (Porat et al., 2018). Studies indicated that in developing countries major food losses occur due to technical and managerial limitations in harvesting techniques, storage, transportation, and processing activities, lack of proper cooling facilities, infrastructure, packaging and marketing systems. Conversely, postharvest loss relates mainly to consumer behavior, quality standard requirements and strict safety policies for fruit and vegetable in developed countries (FAO, 2011, 2015).

\section{Ways to reduce post-harvest losses and waste of fruits and vegetables \\ 3.1. Harvesting Factors}

Harvesting is an important unit operation, that decide upon the quality as well as storage life of produce and helps in preventing huge losses of fruits and vegetables. The goal of a good harvesting is to maximize crop yield, to minimize any crop losses and quality deterioration and to be able to keep the harvested produce in good condition until it is consumed or sold. Maturity standards, harvesting practices, harvesting containers, harvesting tools, field packing and transport conditions to the packinghouse are important factors which affect the postharvest losses and product quality.

To ensure a proper harvest, it's important to set an optimal maturity date of the fruit and vegetable. Harvest maturity refers to the time when the fruit are ready for harvest. Several studies have been performed for the establishment of the ideal time of harvest for the fresh fruits and vegetables regarding the maximum or minimum concentration of the nutritional and functional constituents, and the correlation between them (dos Santos Neto et al., 2017; Fawole \& Opara, 2013). A study by Rahman et al., (2016) indicated that strawberries harvested at $2 / 3$ rd maturity stage was suitable for storing at room temperature up to 3 days. One third matured fruits showed a longer shelf life under room temperature but the quality degraded. Collection of matured fruits is also important, the produce has to be harvested and handled gently. Rough handling; untimely harvesting; lack of appropriate and/or poorly-designed harvesting tools, equipment, and harvesting containers may be causes of losses (Kiaya, 2014).

Size, shape, solidity, fruit opening, firmness, juice content, textural properties, tenderness, color, nutrient composition such as sugar, starch, oil, dry matter content, soluble solid and titratable acidity are examples of maturity induce for some fruits and vegetables. Several parameters such as sugar content, $\mathrm{pH}$ and acidity levels are frequently used to monitor the maturity level of grapes. Harvest date is determined by soluble solids concentration (SSC) of 14 to $17.5 \%$ depending on cultivar and production area. For red and black colored varieties, there is also a minimum color requirement (Mencarelli et al. 2005).Tomato fruit age, surface morphology, color and structure, internal color and structure and seeds slipping when 
fruit is cut, or green color turning pink are some maturity indices which correlate significantly with physico-chemical and nutritional characteristics including total soluble solids (TSS), total titrable acidity (TTA) and protein content (Okiror et al., 2017).

Temperature management after harvesting is an important factor for reducing postharvest losses and extension of shelf life. Several methods might be used for cooling of fresh produce after harvest such as; hydro cooling, evaporative cooling, room cooling, forced air cooling, serpentine forced air cooling, etc. (Elansari, 2009).

The quality of fruit and vegetable also depends on the harvesting method. Poor harvesting practices can lead to irreparable damage to horticultural produce. It is therefore necessary to standardize harvesting techniques for each and every fruit and vegetable in order to minimize damage at the time of harvest. It should be noted that it is important to avoid unnecessary wounding, bruising, crushing or damaging of produce by equipment or containerizing to decrease mechanical damage. Manual and mechanical harvesting or combined methods are used as harvesting methods. In mechanical harvesting numbers of mechanical devices are used for harvesting the produce on commercial scale. Pickers should be careful in harvesting, by gentle digging, cutting, picking and handling or pulling the fruit or vegetable from the plant to minimize damage and waste. If there is various stages of maturity within the crop manual harvesting is applied, while machine-harvesting is usually applied only when an entire crop is harvested at one time. The whole or a part of produce can be harvested by hands only or sharp knives. Knives must be kept sharp and clean in order to prevent spread of virus diseases from plant to plant. Hand held or pole mounted picking shears are also used in fruit and vegetable harvesting (FAO, 1989).

Picking baskets, bags, sacks, carts and buckets which are made of different materials such as plastic, wooden, natural or synthetic fibers can be used as harvesting containers. They should be easy to handle for workers picking fruits and vegetables in the field. Many crops are harvested into bags. Harvesting bags with shoulder or waist slings can be used for fruits with firm skins, like citrus fruits and avocados. Sacks are commonly used for crops such as potatoes, onions and pumpkins. "Food grade" plastics labeled containers made of plastic that can be washed and sanitized between uses are also ideal. Plastic buckets which are smooth and without any sharp edges are suitable containers for harvesting fruits that are easily crushed, such as tomatoes. Proper harvesting container should be selected depending on the type of fruit or vegetable.

\subsection{Best storage and transportation practices}

Transportation is often the most costly factor in the marketing channel. The method of transportation for fresh fruit and vegetables is determined by distance, perishability and the value of the product (Harris, 1988). The globalization of fresh products trade is requiring a need for better long distance transportation systems to preserve product quality. The transportation of fresh produce between the point of source to the point of consumption requires multiple steps. Transportation provides a number of links in the chain of movement of fresh fruits and vegetables from the field to the consumer.

Produce should be kept at optimum conditions during the transport. Adequate temperature control systems and air circulation systems are the most important means to ensure quality preservation of perishables (Vigneault et al., 2009). Cold chain is the logistics system that provides ideal condition to the perishable goods from the point of source to the point of consumption through thermal and refrigerated packaging methods and logistical planning to protect the quality and increase the shelf life of these shipments (Negi \& Anand, 2014).

The shelf life mainly depends on temperature deviations during transport and storage (Hertog et al., 2014). Temperature is the main environmental condition influencing produce quality because it has a profound effect on the rates of biological reactions. Other factors affecting produce quality are: initial quality, environmental humidity and water loss, atmospheric gas concentration, mixed loads, physical injury and stress and transport conditions (surface road conditions, time of the day, etc.) (Vigneault et al., 2009).

The produce is susceptible to physical or chemical damage as well as microbial contamination during transportation. Thus it is critical that a comprehensive food safety and quality program give adequate attention to the management of the transportation environment (www.LSUAgCenter.com).

The transport of fresh fruit and vegetables each variety has widely differing requirements for safe preservation. Whatever the method used, the principles of transport are the same:

*Loading and unloading should be as careful as possible;

* Transition time should be as short as possible;

* The product should be well protected in relation to its suitability to physical injuries; 
* Overheating should not be permitted - maintenance of correct temperature throughout the period of transport;

* Provide ventilation and extraction and air supply;

* Maintain proper relative humidity - water losses by the produce should be restricted to the minimum;

* Whenever possible the transport vehicle should not stop under the sun and the produce protected with a cover;

* Providing shelter from sun and rain at loading and unloading areas (Paltrinieri, 2016).

Storage is the art of keeping the quality of agricultural materials and preventing them from deterioration for specific period of time, beyond their normal shelf life (Kiaya, 2014). Food Produce does not improve in storage. Basic aim of storage is to slow down the ageing process caused due to respiration, moisture loss and disease decay. Storage of fruits and vegetables are essential for extending the period of food availability and avoid the problem of malnutrition. However, the technique is purely based upon the scientific principles. Therefore, for successful storage of fruits and vegetables one should know the basic principles behind (Khan et al., 2017).

There are a wide range of storage structures used throughout the world to successfully store horticultural produce. In general the structure needs to be kept cool (refrigerated, or at least ventilated and shaded) and the produce put into storage must be of high initial quality (Kiaya, 2014).

Controlled Atmosphere Storage (CAS) is controlling the gaseous atmosphere in a store has been shown to improve the maintenance of their postharvest quality over and above the extensions gained by simply controlling the temperature and humidity. A great benefit of controlled atmosphere storage is related to the reduction of food deterioration from pests and diseases, since higher $\mathrm{CO}_{2}$ levels generally have a negative impact on the development and growth of microorganisms. Therefore, storing fruits and vegetables under a controlled atmosphere may significantly reduce the amount of postharvest chemicals used for their protection against insect and microorganisms (Thompson, 1998).

Zero energy cool chambers (ZECC)" are systems used for storage based on the principles of direct evaporative cooling. The main advantage of this on-farm low cost cooling technology are it does not require any electricity or power to operate and materials required to construct this like bricks, sand bamboo, etc. available easily and cheaply (Khan et al., 2017). An evaporative cooling system having an efficiency of $50 \%$, has significant effect on room temperature of non-air-conditioned as well as shaded rooms (Lawrence and Tiwari 1989). Taha et al. (1994) designed and tested a special type of evaporative cooler for its performance under different conditions and concluded that the ambient temperature was reduced by $10-13{ }^{\circ} \mathrm{C}$.

\subsection{Packaging in reduction of post-harvest losses and wastes}

Fresh fruits and vegetables have limited shelf life ranging from a few hours to few weeks at ambient temperature. They are living organisms and continue their physiological and biochemical activities even after harvest. Fresh produce contains $80-90 \%$ of moisture or even more and equilibrate humidity as high as $98 \%$. Therefore they dry rapidly (transpiration) under normal atmospheric conditions. This causes wilting and shriveling due to shrinkage of cells. The existing postharvest loss of fruits and vegetables could be considerably reduced by adopting improved packaging (Verma, 2000).

Different fresh produces need different types of packages depending on their physical, anatomical and physiology (mainly transpiration, respiration and ethylene production rate) nature and susceptibility to microbial decay. Temperature, relative humidity and ventilation also play a very important role in determining the post-harvest life of the fresh produce. Thus, the packaging requirements for fresh produce can be summarized as: (1) protection against microbial contamination and deterioration, (2) protection against bruising and physical injury, (3) protection against moisture / weight loss, (4) providing ventilation for respiration and exchange of gases, (5) slowing down respiration rate, delay ripening and increase storage life, (6) controlling ethylene concentrations in the package (Ahmad \& Siddiqui, 2016; Ahvenainen, 2003; Ramaswamy, 2014).

Packaging is a very important part of the whole chain in reducing food waste. It plays a critical role in extending the shelf life of fresh produce and protecting fresh produce during post-harvest stages. Packaging of fresh fruit and vegetables reduce food losses through the design of better and smarter packaging to keep food fresher for longer. Therefore, appropriate packaging systems should be designed to reduce food losses. The packaging solutions for minimizing food waste during post-harvest are presented in Table 1. It provides some examples of problems that cause food losses along food supply chains and potential packaging solutions. 
Table 1. Packaging solutions for minimizing food waste during post-harvest

\begin{tabular}{|l|l|l|l|}
\hline $\begin{array}{l}\text { Possible reasons for fresh fruits and } \\
\text { vegetables losses }\end{array}$ & Potential packaging solutions \\
\hline $\begin{array}{l}\text { Bruising due to compression of overfilled } \\
\text { packages }\end{array}$ & $\checkmark$ & $\begin{array}{l}\text { The use of shallow and smooth surface containers } \\
\text { Decrease in weight of the produce in container }\end{array}$ \\
\hline $\begin{array}{l}\text { Vibration injury during transportation } \\
\text { roller bruising) }\end{array}$ & $\checkmark$ & $\begin{array}{l}\text { Optimizing transport packaging for shipping } \\
\text { The use of restrainers, individual wrapping and } \\
\text { cushioning }\end{array}$ \\
\hline Impact injury & $\checkmark$ & $\begin{array}{l}\text { The use of rigid containers with cushioning of } \\
\text { each product }\end{array}$ \\
\hline Puncturing injury & $\checkmark$ & $\begin{array}{l}\text { The use of rigid containers with proper grips } \\
\text { The use of smooth containers and handling } \\
\text { equipment }\end{array}$ \\
\hline Water loss or wilting & $\checkmark$ & $\begin{array}{l}\text { The use of advanced packaging techniques such } \\
\text { as MAP and active packaging }\end{array}$ \\
\hline Microbial growth & $\checkmark$ & $\begin{array}{l}\text { Combined treatment of MAP and irradiation } \\
\text { Inadequate ventilation }\end{array}$ \\
\hline Consumer behavior (excessive purchase) & $\checkmark$ & $\begin{array}{l}\text { The use of packaging materials allowed } \\
\text { respiration }\end{array}$ \\
\hline
\end{tabular}

Packaging materials used in traditional packaging methods may protect fresh fruits and vegetables against external factors at a certain level. Appropriate packaging materials and advanced packaging systems need to be developed to reduce post-harvest losses and increase the shelf life of fresh fruit and vegetables. Actually, there are various advanced packaging systems available for the fresh fruits and vegetables packaging. Modified atmosphere packaging (MAP), active packaging and smart (intelligent) packaging technologies are considered the most important advanced packaging technologies. They are innovative concept that refers to the incorporation of bioactive compounds into packaging systems or modification of atmosphere within package with the aim of maintaining the quality or extending the shelf-life of fresh produce. For example, the shelf life of the packaged products can be extended by 50 $200 \%$ by using well-designed MAP (Siddiqui, 2016). The changing shelf life of some products under normal weather conditions and modified atmosphere packaging technology is shown in Table 2. Even though the contribution of advanced packaging systems on shelf life of fresh produce is tremendous, their industrial use is not very common (Siddiqui et al., 2018).

Table 2. Shelf life of certain fresh produce in MAP vs. natural atmosphere

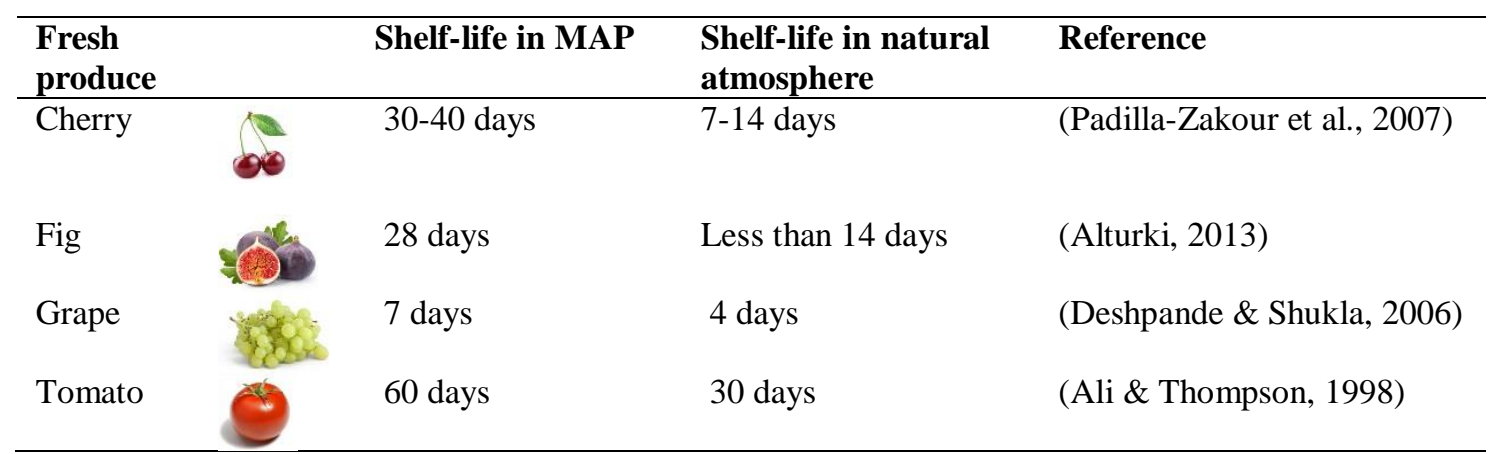




\section{Conclusion}

Minimizing postharvest losses of fruit and vegetable is a very effective way of fighting poverty, ensuring food security and maintaining the quality of produce. In many developing countries, major causes of fresh fruit and vegetable loss are the lack of infrastructure (poor harvesting, transportation, storage and processing technologies) while fruit and vegetable losses in developed countries occur largely at consumer stage. Use of the appropriate post-harvest innovations and technologies is necessary to reduce post-harvest losses. Along with post-harvest technologies, coordination and management of post-harvest stages successfully have an important role in reduction of post-harvest losses.

\section{Acknowledgement}

The authors would like to thank the many colleagues and institutions in Turkey and in participating countries who have contributed to the work of the "Best Innovative Approach to Minimize Post Harvest Losses within Food Chain for VET" project funded by the Erasmus+ Program of the European Union.

\section{References}

Ahmad, M.S., \& Siddiqui, M.W. (2015). Factors affecting postharvest quality of fresh fruits Postharvest quality assurance of fruits (pp. 7-32): Springer.

Ahmad, M.S., \& Siddiqui, M.W. (2016). Postharvest quality assurance of fruits. Chapter, 2, 7-12.

Ahvenainen, R. (2003). Novel food packaging techniques: Elsevier.

Ali, B., \& Thompson, A.K. (1998). Effects of modified atmosphere packaging on post harvest qualities of pink tomatoes. Turkish Journal of Agriculture and Forestry, 22(4), 365-372.

Alturki, S. (2013). Utilization of modified atmosphere packaging to extend the shelf-life of fresh figs. Biotechnology, 12(2), 81-86.

Azabağaoğlu, M.Ö. (2018). Investigating fresh fruit and vegetables losses at contemporary food retailers. Sosyal Bilimler Araştırma Dergisi, 7(4), 55-62.

Deshpande, S., \& Shukla, B. (2006). Modified atmosphere packaging of table grapes in polymeric films under ambient conditions for increased storage life. Paper presented at the International Symposium on Grape Production and Processing 785.

dos Santos Neto, J.P., de Assis, M.W.D., Casagrande, I.P., Júnior, L.C.C., \& de Almeida Teixeira, G.H. (2017). Determination of 'palmer'mango maturity indices using portable near infrared (vis-nir) spectrometer. Postharvest Biology and Technology, 130, 75-80.

Elansari, A.M. (2009). Design aspects in the precooling process of fresh produce. Quality Retention During Postharvest Handling Chain, Sivakumar, D.(Ed.), 49-57.

Food and Agriculture Organization of the United Nations (FAO). (1989). Prevention ofpost-harvest food losses: fruits, vegetables, and root crops. A training manual. Available at: http://www.fao.org/docrep/T0073E/T0073E03.htm\#5.\%20Harvesting\%20and\%20field\%20hand ling

Food and Agriculture Organization of the United Nations (FAO). (2011). Global food losses and food waste - extent, causes and prevention. Available at: http://www.fao.org/docrep/014/mb060e/mb060e.pdf. 
Food and Agriculture Organization of the United Nations (FAO). (2013). Food Losses and Waste in Turkey, Country Report, 48 s. Available at: http://www.fao.org/3/a-au824e.pdf

Food and Agriculture Organization of the United Nations (FAO). (2015). Global Initiative on Food Loss and Waste Reduction. Available at: http://www.fao.org/3/a-i4068e.pdf.

Food and Agriculture Organization of the United Nations (FAO). (2016). Available at: http://www.fao.org/faostat/en/\#data.

Fawole, O.A., \& Opara, U.L. (2013). Developmental changes in maturity indices of pomegranate fruit: A descriptive review. Scientia Horticulturae, 159, 152-161.

Gustavsson, J., Cederberg, C., Sonesson, U., Otterdijk, R., \& Meybeck, A. (2011). Global food losses and food waste, food and agriculture organization of the united nation (fao). Swedish Institute for Food and Biotechnology, Düsseldorf, Interpack.

Harris. S.R. (1988). Production is only half the battle - A training manual in fresh produce marketing for the Eastern Caribbean, Food And AgrıcultureOrganisation Of The United Natıons, Bridgetown, Barbados.

Hertog, M.L., Uysal, I., McCarthy, U., Verlinden, B.M., \& Nicolaï, B.M. (2014). Shelf life modelling for first-expired-first-out warehouse management. Philosophical Transactions of the Royal Society of London A: Mathematical, Physical and Engineering Sciences, 372(2017), 20130306.

International Refrigeration Institute (IIR) (2009). The role of refrigeration in worldwide nutrition. 5th Informatory Note on Refrigeration and Food. Available at: http://www.iifiir.org/userfiles/file/publications/notes/NoteFood_05_EN.pdf

Kader, A. (1995). Maturity, ripening, and quality relationships of fruit-vegetables. Strategies for Market Oriented Greenhouse Production 434, 249-256.

Kasso, M., \& Bekele, A. (2016). Post-harvest loss and quality deterioration of horticultural crops in dire dawa region, ethiopia. Journal of the Saudi Society of Agricultural Sciences.

Khan F., Bhat S., Narayan S. (2017). Storage Methods for Fruits and Vegetables.

Kiaya, V. (2014). Post-harvest losses and strategies to reduce them. Technical Paper on Postharvest Losses, Action Contre la Faim (ACF).

Kitinoja, L., \& AlHassan, H. (2010). Identification of appropriate postharvest technologies for small scale horticultural farmers and marketers in sub-saharan africa and south asia-part 1. Postharvest losses and quality assessments. Paper presented at the XXVIII International Horticultural Congress on Science and Horticulture for People (IHC2010): International Symposium on 934.

Lawrence, S.A., Tiwari, G.N. (1989). Performance study of an evaporative cooling system for a typical house in port Moresby. Solar Wind Technol. 6(6):717-724.

LSU AgCenter. Transportation of Fresh Produce: Best Practices To Ensure On-farm Food Safety. Available at: https://www.lsu.edu/agriculture/plant/extension/hcpl-publications/2_Pub.3442TransportationofFreshProduce-BestPracticestoEnsureOn-FarmFoodSafety.pdf 
Mencarelli, F., Bellincontro, A., 2005. GRAPE: Post-harvest Operations, Food and Agriculture Organization Press.

Negi, S., \& Anand, N. (2014). Supply chain efficiency: An insight from fruits and vegetables sector in india. Journal of Operations and Supply Chain Management, 7(2), 154-167.

Okiror, P., Lejju, J.B., Bahati, J., Rugunda, G.K., \& Sebuuwufu, C.I. (2017). Maturity indices for tomato (solanum lycopersicum 1.), cv. Ghalia 281 in central uganda. African Journal of Agricultural Research, 12(14), 1196-1203.

Özcan, M. 2010. Bahçe Ürünlerinde Muhafaza ve Pazarlama Ders Notları. Ondokuz Mayıs Üniversitesi Ziraat Fakültesi Ders Notları.

Özdemir, A. E., Dündar Ö., Ertürk E., Dilbaz R. (2003). Bazı Yörelerimizde Yetiştirilen Starking Delicious elmalarında Derim Öncesi ve Derim Sırasında Görülen Kayıpların Belirlenmesi .IV Ulusal Bahçe Bitkileri Kongresi 08-12 Eylül Antalya s. 166-168.

Paltrinieri, G. (2016). Handling fruits, vegetables and root crops, Food and Agriculture Organization of United Nations.

Padilla-Zakour, O., Ryona, I., Cooley, H., Robinson, T., Osborne, J., \& Freer, J. (2007). Shelf-life extension of sweet cherries by field management, post-harvest treatments and modified atmosphere packaging. New York fruit quarterly.

Porat, R., Lichter, A., Terry, L.A., Harker, R., \& Buzby, J. (2018). Postharvest losses of fruit and vegetables during retail and in consumers' homes: Quantifications, causes, and means of prevention. Postharvest biology and technology.

Rahman, M.M., Moniruzzaman, M., Ahmad, M.R., Sarker, B., \& Alam, M.K. (2016). Maturity stages affect the postharvest quality and shelf-life of fruits of strawberry genotypes growing in subtropical regions. Journal of the Saudi Society of Agricultural Sciences, 15(1), 28-37.

Ramaswamy, H.S. (2014). Post-harvest technologies of fruits \& vegetables: DEStech Publications, Inc.

Ray, R., \& Ravi, V. (2005). Post harvest spoilage of sweetpotato in tropics and control measures. Critical reviews in food science and nutrition, 45(7-8), 623-644.

Siddiqui, M.W. (2016). Eco-friendly technology for postharvest produce quality: Academic Press.

Siddiqui, M. W., Rahman, M. S., Wani, A.A. (2018). Innovative Packaging of Fruits and Vegetables: Strategies for Safety and Quality Maintenance. Apple Academic Press.

Taha, A., Rahim, A., \& Eltom, O. (1994). Evaporative cooler using a porous material to be used for reservation of food. Renewable Energy, 5(1-4), 474-476.

Thompson, A.K. (1998). Controlled atmosphere storage of fruits and vegetables. CAB International, London.

Verma, L. (2000). Postharvest technology of fruits and vegetables: General concepts and principles (Vol. 1): Indus Publishing. 
Vigneault, C., Thompson, J., Wu, S., Hui, K.C., \& LeBlanc, D.I. (2009). Transportation of fresh horticultural produce. Postharvest technologies for horticultural crops, 2, 1-24.

WRAP, 2008. Helping Consumers Reduce Fruit and Vegetable Waste: Final Report. Available at: http://www.wrap.org.uk/sites/files/wrap/WRAP\%20RTL044-001\%20Final\%20report.pdf . 